\title{
University Students' Perceptions of the Key Elements of Cooperative Learning
}

\section{Tomoko Hashimoto \\ Meiji University}

\section{Reference Data:}

Hashimoto, T. (2020). University students' perceptions of the key elements of cooperative learning. In P. Clements, A. Krause, \& R. Gentry (Eds.), Teacher efficacy, learner agency. Tokyo: JALT. https://doi.org/10.37546/JALTPCP2019-16

In this study I examined students' perceptions of the way cooperative learning $(C L)$ was used in their classroom setting. $C L$ involves five key elements: positive interdependence (PI), face-totheir classroom setting. $C L$ involves five key elements: positive interdependence (PI), face-to-
face promotive interaction (FF), individual accountability (IA), interpersonal and small group skills (IS), and group processing (GP). For this study, first-year university students from three classes participated in informal $\mathrm{CL}$ (semistructured), formal $\mathrm{CL}$ (structured), and teacher-led instruction. At the end of the research period, students' perceptions of these were rated. Analyses showed that for PI and IS, the mean score of the formal CL class was significantly higher than the teacher-led instruction class, but that there were no significant differences between FF, IA, and GP for these two groups. Student perceptions of the informal $C L$ class did not show any significant difference when compared to the formal $\mathrm{CL}$ class nor the teacher-led instruction class for any of the five key elements.

本研究は、協同学習 $(\mathrm{CL}$ ) の5つの基本要素について、学生の認識を調べたものである。 5 つの基本要素とは、互恵的な相

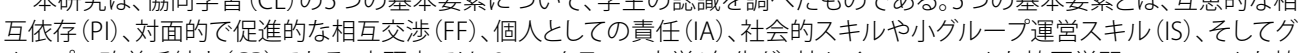
ループ改善手続き(GP) である。本研究では、3つのクラスの大学1年生が、其々インフォーマルなな協同学習、フォーマールな協 同学習、そして、教員主導の学習を体験した後、協同学習の5つの基本要素の重要度を評価した。分析の結果、フォーマルルな

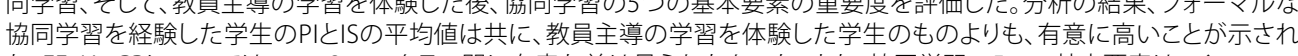
た。FF、IA、GPについては、この2つのクラス間に有意な差は見られなかった。また、協同学習の5つの基本要素は、インフォー マルな協同学習とフォーマルな協同学習、インフォーマルな協同学習と教員主導の学習のどちらを比較しても、有意差が認め られなかった。 apanese educational policies are overseen by MEXT (the Ministry of Education, Culture, Sports, Science and Technology), which has been encouraging the use of active learning in tertiary education. This is being done in order to shape individuals who can develop innovative ideas and become future leaders in what is becoming an increasingly unstable global economic environment (MEXT, 2014). According to MEXT (2014), active learning is

the general term used for pedagogy and learning method incorporating learners' active participation which differs from unidirectional teacher instruction. By actively being involved, it aims to nurture learners' general abilities in cognition, ethics, social skills, cultural skills, intelligence and experience. It includes studies in discovery, problem solving, experience, and survey but in-class group discussions, debates and group work are also effective ways of active learning. (p. 37)

Within this rubric, group work conducted in the classroom environment is considered to be a form of active learning (MEXT, 2017). Although there are many ways to implement active learning, the focus of this paper will be on in-class group work. One type of group work that is somewhat structured and that all members of the group are actively involved in is cooperative learning (CL) (MEXT, 2017).

According to Johnson, Johnson, and Holubec (1993), the aim of CL is to enrich students' learning by encouraging them to develop skills that help them to work cooperatively and attain joint goals in small groups. Furthermore, Sekita and Yasunaga (2005) suggested that CL deepens students' understanding of subject material, hones their group working skills, and fosters the idea that group work helps to obtain global leadership skills. The ultimate goal of $\mathrm{CL}$ is to reach "a desired future state of competence or mastery in the subject area being studied" through group work (Johnson, Johnson, \& Smith, 1991, p. 6). Fundamentally, cooperative and competitive learning stand in contrast with one another, although the two can coexist in the same classroom. For example, competition and cooperation can occur when students work in groups 
during class, but these groups compete against one another on tasks (Nunan, 1992). The implementation of $\mathrm{CL}$ in the classroom context requires careful planning on the part of teachers and active participation by students, although the degree of each may differ according to the type of CL employed.

Recently, CL has been gaining attention in Japan against the backdrop of MEXT's policy regarding the direction of tertiary education. As a result, more teachers are incorporating $\mathrm{CL}$ into their classrooms. Although CL has previously been implemented in Japan, not every student leaves the classroom having had a positive experience with CL (Sekita \& Yasunaga, 2005). Furthermore, Japanese students of today live in a relatively competitive society where they are constantly measured against each other in ongoing assessments and in the labour market. Many educational institutions also divide their students into classes according to academic competence and this may work against the formation of cooperative environments (Erikawa, 2012; Kobayashi, Suzuki, \& Suzuki, 2016). This competitive focus persists in spite of evidence that suggests that cooperation enhances the psychological well-being of students as well as their academic achievement (Johnson, Maruyama, Johnson, Nelson, \& Skon, 1981). Thus, it seems that teachers should try to create a classroom environment in which students can appreciate the importance of and develop skills through $\mathrm{CL}$.

\section{Previous Studies of Cooperative Learning}

Evidence suggests that the benefits of $\mathrm{CL}$ are greater than other forms of group-related activities, such as peer tutoring or voluntary study groups (Damon \& Phelps, 1989; Sharan, 1985; Slavin, 1996; Storch, 2002). Moreover, there is indication that CL has positive effects on students' psychological health, confidence, schoolwork, reasoning ability, and interpersonal relationships. In addition, $\mathrm{CL}$ encourages students to be more open to different ideas (Johnson et al., 1991; Johnson, Johnson, \& Holubec, 1993, 2002). In Japan, Mineshima (2014) conducted an activity called learning through discussion to assess the general effects of $\mathrm{CL}$ on university students, which resulted in a positive increase in student perceptions of CL. A study by Sugie (2004) introduced the connection between $\mathrm{CL}$ and its history in educational practice in Japan and also gave empirical evidence of how $\mathrm{CL}$ amongst teachers helped improve educational practice. Erikawa (2012) also made 14 practical reports on a variety of formal and informal CL uses in elementary, secondary, and higher education settings, including EFL teaching contexts. Results indicated that CL not only increases academic achievement but also helps to decrease behavioral problems in class. Research also shows the benefits of $\mathrm{CL}$ in writing, exams, and speaking courses as well as across a broad range of other modalities (Isoda,
2012; Makino, 2013). Generally, studies have shown that CL can bring better academic performance, particularly in reading comprehension, to the classroom than pedagogical approaches that promote individualism (Stevens, Madden, Slavin, \& Farnish 1987; Stevens, Slavin, \& Farnish, 1991)

Types of Cooperative Learning

Although Johnson et al. (1991) divided CL into informal, formal, and cooperative base groups, this paper will only focus on the first two. This is because, unlike the other $\mathrm{CL}$ approaches, cooperative base groups presuppose cooperation and support amongst students in areas other than academic achievement, such as students' private lives.

Informal $C L$ consists of groups of two to three students. The groups meet together in class to talk over what was discussed in the lesson with the aim of filling in any gaps in knowledge that each student may have about class material. After teacherled instruction, students are put into ad hoc groups and undertake a task. These ad hoc groups can be created in various ways such as seating arrangements or a problem posed by the teacher. These group activities last for a maximum of one lesson. Pre- and postdiscussion group talks can be conducted as well. The 3 -step procedure which is used is introductory focused discussion, turn-to-your partner discussion, and closure focused discussion (Johnson et al., 1991). Introductory focused discussion is when the teacher introduces the group activity. Turn-to-your partner discussion is a technique in which students talk to their partners or other group members and conduct an activity specific to a particular lesson. Closure focused discussion is when the class is brought back together, and the teacher wraps up the lesson. Closure focused discussion leads students to link their prior learning to new information from the lesson through discussions initiated by the teacher. It also prepares students for homework tasks and the following lesson. An example of informal $\mathrm{CL}$ is for students to talk about what club activities they engaged in during high school as a review of grammar on past verb forms. First, the teacher poses a relevant question to the class, then students pair up and take turns sharing their experiences as a fluency task. Next, the teacher asks a couple of groups to share what they talked about with the rest of the class. Finally, the teacher sets a writing assignment that encourages the use of the past verb form(s) studied. Students are expected to be ready to share this writing with a partner in the following lesson.

In contrast, formal $C L$ is more directly incorporated into the curriculum and lasts for one or more lessons with the aim of achieving "shared learning goals and complet[ing] jointly specific tasks and assignments" (Johnson et al., 1991, p. 14). Groups are ideally composed of two to three students but can have up to a maximum of four members. 
Lesson tasks are carried out using four stages in which the teacher makes pre-

instructional decisions, sets tasks, monitors groups, and intervenes when necessary.

Students are then expected to process and evaluate what they have learned. In formal CL, the teacher's role is not to teach content to students, rather it is to encourage students to learn content for themselves through activities (Johnson et al., 1991). When they need assistance, students are encouraged to consult with their group members first, rather than the teacher. They are also advised to share ideas and materials and encourage each other, and each student is accountable for contributing to the group. In formal CL, it is important that students explain verbally to each other what they are learning. Verbal communication is prioritized because no matter how wonderful an idea is, students need to share it in order to collectively reach a more thorough understanding (Johnson et al., 1991).

An example of a formal $\mathrm{CL}$ activity is translating the lyrics of an English nursery rhyme, such as "Where is Thumbkin?," into Japanese and presenting the translation to the class. Task details should include information on how much physical movement a song chosen by the students should have, where they can find such songs, who they should conduct this activity for, and the deadline. Taking "Where is Thumbkin?" as an example, the purpose of the assignment is for students to gain the skills to teach a group of children, in Japanese, an English nursery rhyme that requires physical activity, to encourage the children to learn through activity. Grouping can be based on in-class test scores. Students will probably need two lessons to work on translating this song into Japanese and learning the finger movements. Group presentations can be made in the third lesson. While the students are undertaking the activity, the teacher should observe each group and provide assistance, as needed. Lastly, students should give each other feedback on how well the task was achieved and what could have been done differently after making their presentations. Table 1 summarizes the differences between informal and formal CL.
Table 1. Summary of Differences Between Informal and Formal Cooperative Learning

\begin{tabular}{|c|c|c|}
\hline Measure & Informal & Formal \\
\hline Group size & Two to three students & Two to four students \\
\hline Duration & One lesson & One or several lessons \\
\hline Aim & $\begin{array}{l}\text { To fill in any gaps in knowledge } \\
\text { that individuals may have about } \\
\text { class material }\end{array}$ & $\begin{array}{l}\text { To achieve shared learning } \\
\text { objectives and complete jointly } \\
\text { specific tasks \& assignments, etc. }\end{array}$ \\
\hline Outline & $\begin{array}{l}\text { Once every } 10 \text { to } 15 \text { minutes, } \\
\text { students are put into ad hoc } \\
\text { groups and are asked to review } \\
\text { information they have covered in } \\
\text { class, answer questions, etc. }\end{array}$ & $\begin{array}{l}\text { Students are in the same group } \\
\text { until task completion. Teacher's } \\
\text { role is to uncover material with } \\
\text { the students, not cover material } \\
\text { for the students }\end{array}$ \\
\hline \multirow[t]{4}{*}{ Implementation } & $\begin{array}{l}\text { 1. introductory focused } \\
\text { discussion }\end{array}$ & $\begin{array}{l}\text { 1. teacher makes pre- } \\
\text { instructional decisions }\end{array}$ \\
\hline & $\begin{array}{l}\text { 2. turn-to your partner } \\
\text { discussion }\end{array}$ & $\begin{array}{l}\text { 2. teacher announces task and } \\
\text { goes over CL elements }\end{array}$ \\
\hline & $\begin{array}{l}\text { 3. closure focused } \\
\text { discussion }\end{array}$ & $\begin{array}{l}\text { 3. teacher monitors groups and } \\
\text { intervenes when necessary }\end{array}$ \\
\hline & & $\begin{array}{l}\text { 4. students provide each other } \\
\text { feedback }\end{array}$ \\
\hline
\end{tabular}

\section{Elements of Cooperative Learning}

The first element of $\mathrm{CL}$ is positive interdependence $(\mathrm{PI})$, the idea that everyone in the group needs to participate in order to complete a task (Johnson \& Johnson, 2009). Jacobs, in an interview, described this as "a sink or swim together feeling among group mates" (Kimura, 2009, p. 13). Positive interdependence arises when the action of each group member brings about the accomplishment of the group's objective (Johnson \& Johnson, 2009). The second element of CL is individual accountability (IA), wherein each group member realizes that their contribution must be made in relation to the group's objective (Davis, 1999). CL's third element is face-to-face promotive interaction (FF). This 
requires students to work together as a group to promote each other's success. Active participation in discussion, involvement, encouragement, and praising each other's learning are necessary for this form of CL to be successful (Johnson \& Johnson, 1999).

Cooperative interpersonal and small group skills (IS) is the fourth element of CL, which helps students attain their goals and improve communication skills. According to Johnson and Johnson (1999), "Leadership, decision-making, trust-building, communication, and conflict-management skills have to be taught just as purposefully and precisely as academic skills" (pp. 27-28). In order for students to work effectively as a group, they must be socially conscious of one another and typically need to ask for repetition, listen attentively, speak at an appropriate volume level, paraphrase, ask for help, make suggestions, check understanding, keep the group on task, ask about feelings, disagree politely, and give reasons (Jacobs \& Kline Liu, 1996).

The last of the five key elements is group processing (GP). This involves talking over what is being learned or was learned during an activity as well as discussing how the group is functioning as a collective. Students should also be given sufficient time to discuss what improvements could be made, reflect on group functioning, and identify what kinds of verbal and practical engagements in the task were or were not helpful (Johnson \& Johnson, 1999).

Regardless of whether informal or formal CL is used in the classroom, they have similarities. Although categorizations of these elements differ (e.g., Kato, Bolstad, \& Watari, 2015), Johnson and Johnson's (1999) are probably the most commonly referred to. Out of the five key elements of CL proposed by Johnson and Johnson (1999), positive interdependence and individual accountability are the two that are most widely accepted by practitioners (Kato et al., 2015; McCafferty, Jacobs, \& Iddings, 2006).

\section{Research Aim}

In this study, I attempted to shine some light on CL by investigating Japanese university students' perceptions of the value of Johnson and Johnson's (1999) five elements to their learning. This was done by comparing different groups of students' perceptions in the context of whether they received informal or formal CL lessons or non-CL teacherfronted lessons. It is hoped that this information will provide teachers with some guidance as to which factors are best to focus on to effectively implement CL in their classrooms in the Japanese context.

\section{Methodology}

\section{Measures}

A five-item questionnaire (see Appendix A), based on the five key elements, was used to measure students' perceptions of CL. The questionnaire was created because there was no instrument available that measured students' perception of the five key elements at the time the study was conducted. It was created in Japanese to make sure the participating students had a clear understanding of what was being asked. Participants were asked to rate each item on a 5-point Likert scale.

\section{Participants}

The participants in this study were 1st-year EFL students at a 4-year university in Tokyo $(N=85)$. The participants were in a beginner-level English class studying core English reading, writing, speaking, and listening skills. The participants were between the ages of 18 and 19 years old and were assigned to their class at the beginning of their freshman year. The English proficiency of the participants was at the CEFR A1-A2 level.

\section{Procedure}

Three classes of students participated in the study, which lasted for half a semester. Class $\mathrm{A}(n=30)$ were given instruction using informal CL, Class $\mathrm{B}(n=27)$ engaged in formal $\mathrm{CL}$, and Class C $(n=28)$ were only given teacher-led instruction without $\mathrm{CL}$ activities. The participants gave informed consent, and the project was cleared with the university's institutional review board. At the beginning of the study, the five key elements of $\mathrm{CL}$ were explained in a lecture in Japanese, only to the participants from Classes A and B. After this, a question-and-answer session was held to clarify the five elements. Examples were given to make sure that the students had a clear understanding of the meaning of each key element, and a verbal class quiz was used to concept-check understanding. Students were asked to sign two copies of the Understanding of the Five Key Elements of $C L$ document (see Appendix B). The students were given a copy of this agreement to remind them of lesson aims and also to refer to should they need to refresh their understanding of any of the key elements. Participants in Class $C$ did not get an explanation of the five key elements of $\mathrm{CL}$ as they were the control group. For this class, perception of these elements was measured without engaging in any $\mathrm{CL}$. 


\section{Conducting Informal CL, Formal CL, and Teacher-Led Instruction}

Each class received their respective course of instruction from Lessons 2 to 7 of the semester. The content of the course was largely geared towards early childhood education and care as the participants were training to become early childhood education providers. During each 90-minute lesson, Class A engaged in informal CL activities including rally coaching and think-pair-share, proposed by Kagan (1994). Rally coaching is a form of participant-observation learning wherein the teacher assigns a task to a group of students and each group takes turns conducting the assignment. One person in each group was assigned to work on the task while the others listened and observed the process. Members of the group who were not working on the task were asked to coach the student doing the task if she or he was having difficulty. The thinkpair-share task is an activity in which the teacher asks the class a question for students to think about individually. Students were put into groups and asked to discuss their ideas. Then the teacher asked the students to share what they talked about in their groups with the rest of the class.

Class $\mathrm{B}$ engaged in formal $\mathrm{CL}$ activities. For example, the students created a dialogue between a parent and an early childhood education provider. Then they had to present this in front of the class. Another activity was the game Who am I? In this game, students were put into groups and asked to think of an animal or object. Then they brainstormed vocabulary that described the animal or object and made a note of these. Next, they wrote several sentences starting with "I am ..." and finishing the sentence with a description of the animal or object. Two groups were then combined and they quizzed each other about the animal or object. The group that was not reading their sentences aloud was supposed to guess what animal or object was being described.

Class $\mathrm{C}$ did not engage in any group work. In this class, reading, writing, listening, and speaking activities were all done individually. For example, as a reading assignment for this class, students had to individually read a passage in English and then answer questions posed by the teacher. For one of their writing assignments, the participants were asked to write a paper about what kind of early childhood education provider they would like to become. Students then handed this in to the teacher who made corrections and provided comments.

At the end of the semester, all of the participants were given a questionnaire to evaluate their perceptions of the five key elements of $\mathrm{CL}$ (see Appendix A).
Results

There were significant differences for PI and IS, but not for FF, IA, or GP (see Table 2). To see what the difference was for PI and IS, post hoc Tukey HSD tests were conducted. These tests indicated that for PI, the mean score of Class B was significantly higher than Class $\mathrm{C}$, suggesting that students who engaged in formal $\mathrm{CL}$ perceived that success as a group depended on each student's accomplishments more than did students who received only teacher-led instruction. In addition to this, the tests indicated that there were no significant differences between Classes A and B, nor between Classes A and C. Moreover, the post hoc analyses also revealed that for IS, the mean score for Class B was significantly higher than Class $\mathrm{C}$. There was no significant difference for IS between Classes A and B, nor between Classes A and C.

Table 2. Results of One-Way Nonrepeated Measures ANOVAs of the Five Key Elements of CL

\begin{tabular}{lccccccc}
\hline & \multicolumn{7}{c}{ Group Means $(S D)$} \\
\cline { 2 - 8 } Element & $\mathrm{Q}$ & Class A & Class B & Class C & $d f$ & $F$ & $p$ \\
\hline Positive interdependence & 1 & 4.27 & 4.63 & 4.11 & 2 & 3.44 & $.04^{*}$ \\
& & $(0.91)$ & $(0.56)$ & $(0.74)$ & & & \\
Interpersonal and small group & 4 & 4.00 & 4.11 & 3.54 & 2 & 3.83 & $.03 *$ \\
skill & & $(0.79)$ & $(0.93)$ & $(0.74)$ & & & \\
Face-to-face promotive & 2 & 4.03 & 4.30 & 3.86 & 2 & 1.77 & .18 \\
interaction & & $(0.89)$ & $(0.95)$ & $(0.76)$ & & & \\
Individual accountability & 3 & 4.07 & 4.48 & 4.00 & 2 & 3.16 & .05 \\
& & $(0.87)$ & $(0.70)$ & $(0.72)$ & & & \\
Group processing & 5 & 3.93 & 4.04 & 3.79 & 2 & 0.79 & .46 \\
& & $(0.87)$ & $(0.65)$ & $(0.69)$ & & & \\
\hline
\end{tabular}

Note. $\mathrm{Q}=$ question number (see Appendix A).

$* p<.05$

Discussion

Previous studies have indicated that $\mathrm{CL}$ is often a better form of learning than competitive or individualistic learning. The results of this study seem to point in the same direction and suggest that engagement in CL activities appears to be related to 
the student perception that group members are jointly responsible when conducting group work. Formal CL also seems to be connected with student perceptions of the importance of interpersonal skills. For students in the teacher-led instruction class, the results showed that their perception of the importance of the five key elements of CL was consistently lower than the other two classes. A possible explanation for this could be their lack of participation in CL. However, as there was no significant difference between the three classes for FF, IA, and GP, it may be dangerous to pinpoint nonengagement of $\mathrm{CL}$ as the definite cause of this. Slavin (2014) suggested ways to improve student perceptions of these constructs, including randomly picking students to represent the group; rearranging the layout of the classroom so that students are physically closer to each other; and stressing the importance of learning about, practicing, and refining communication skills. Until now, MEXT may have assumed that there is an anmoku no ryoukai (暗黙の了解 [tacit understanding]) amongst Japanese people about the nature of social relations. However, as Japan becomes more globalized, this can no longer be presumed. Consequently, there is a need for students to learn interaction skills that are adaptable to a variety of cultural contexts. To this end, MEXT may want to emphasize the need to develop camaraderie and respect for one another as a precursor to implementing $\mathrm{CL}$ in classrooms.

\section{Limitations}

One limitation of this study was that a pretest measure of students' perceptions of $\mathrm{CL}$ was not taken to quantify any changes in their views of CL. Had this been done, it may have been possible to see how student perceptions altered as they took part in CL. The timing in which the study was administered may also have influenced the participants perceptions of CL. For example, if the study had been conducted in the fall term of the participants' 1st year or later, the students may have already gotten to know each other better and learnt more about each others' previous experiences with group work and their sociocultural background. This, in turn, could have affected students' perceptions of $\mathrm{CL}$ and sped up student adoption of cooperative learning strategies. Further research could also compare Japanese students' perceptions of other CL forms, such as cooperative base groups, that were not examined in this study.

\section{Conclusion}

This study looked into university students' perceptions of the five key elements of $\mathrm{CL}$ moderated by the type of instruction method they engaged in. Analyses showed that perceptions of the benefits of positive interdependence and interpersonal and small group skills scores were significantly higher for students who engaged in semistructured cooperative learning lessons than those who took teacher-fronted lessons. Structured cooperative learning lessons did not seem to impact student perceptions of these two factors. Moreover, instructional style did not have any significant influence on student perceptions of face-to-face promotive interaction, individual accountability, and group processing. As there is a need for young Japanese people to become more engaged with the modern globalized economy, MEXT is aiming to foster individuals who have the skills demanded of global leaders. The CL skills that were examined in this study are not only applicable in EFL settings but facilitate the broader development of the kinds of life skills that contribute to success in the global economy. As such, this study has added to the growing body of evidence that the promotion of cooperative learning may have extensive benefits to students' learning and to broader society.

\section{Bio Data}

Tomoko Hashimoto is a doctoral student at Meiji University and teaches part-time at several universities in the Tokyo area. She believes in the importance of linking theory to practice and is especially interested in the psychological aspects of language learning. $<$ hondat1.th@gmail.com>

\section{References}

Damon, W., \& Phelps, E. (1989). Critical distinctions among three approaches to peer education. International Journal of Educational Research, 58, 9-19.

https://doi.org/10.1016/0883-0355(89)90013-X

Davis, B. G. (1999). Cooperative learning: Students working in small groups. Speaking of Teaching, 10(2), 1-4. Retrieved from https://commons.trincoll.edu

Erikawa, H. (2012). 協同学習を取り入れた英語授業のすすめ [English lessons incorporating cooperative learning]. Tokyo: Taishuukan shoten.

Isoda, T. (2012). Effectiveness of cooperative learning in an English class. 広島外国語教育研究 [Research on Hiroshima Foreign Language Education], 15, 65-73.

Jacobs, G. M., \& Kline Liu, K. (1996). Integrating language functions and collaborative skills in the second language classroom. TESL Reporter, 29, 21-33. Retrieved from https://ojs.lib.byu.edu/spc/index.php/TESL/article/view/3586/3360

Johnson, D. W., \& Johnson, R. T. (1999). What makes cooperative learning work? In D. Kluge, S. McGuire, D. Johnson, \& R. Johnson (Eds.), JALT applied materials: Cooperative learning (pp. 23-36). Tokyo: JALT. 
Johnson, D. W., \& Johnson, R. T. (2009). An educational psychology success story: Social interdependence theory and cooperative learning. Educational Researcher, 38(5), 365-379. https://doi.org/10.3102/0013189X09339057

Johnson, D. W., Johnson, R. T., \& Holubec, E. J. (1993). Circles of learning: Cooperation in the classroom (4th ed.). Edina, MN: Interaction Book Company.

Johnson, D. W., Johnson, R. T., \& Holubec, E. J. (2002). Circles of learning: Cooperation in the classroom (5th ed.). Edina, MN: Interaction Book Company.

Johnson, D. W., Johnson, R. T., \& Smith, K. A. (1991). Active learning: Cooperation in the college classroom. Edina, MN: Interaction Book Company.

Johnson, D., Maruyama, G., Johnson, R., Nelson, D., \& Skon, L. (1981). Effects of cooperative, competitive, and individualistic goal structures on achievement: A metaanalysis. Psychological Bulletin, 89, 47-62. https://doi.org/10.1037/0033-2909.89.1.47

Kagan, S. (1994). Cooperative learning. San Clemente, CA: Kagan Publishing.

Kato, Y., Bolstad, F., \& Watari, H. (2015). Cooperative and collaborative learning in the language classroom. The Language Teacher, 39(2), 22-26. https://doi.org/10.37546/JALTTLT39.2

Kimura, H. (2009). Controversy over cooperative learning: An interview with Dr. George M. Jacobs. The Language Teacher, 33(8), 13-16. Retrieved from https://jalt-publications.org/sites/default/ files/pdf-article/33.09-art3_0.pdf

Kobayashi, A., Suzuki, T., \& Suzuki, E. (2016). 現場ですぐに使えるアクティブラーニング実践 [Practical ideas of active learning activities that can be immediately used in classrooms]. Tokyo: Sangyou Nouritsu Daigaku Shuppanbu.

Makino, M. (2013). 英語スピーチにおける協同学習の有効性:リメディアル教育を必要とする大学生を対象 として [Effectiveness of using English speech activities to university students in need of remedial education]. 近畿大学教養外国語セン夕一紀要 (外国語編) [Kinki University Center for Liberal Art and Foreign Language Education journal (Foreign language edition)], 4(1), 99-116. Retrieved from https://kindai.repo.nii.ac.jp/?action=pages_view_main\&active_action=repository_view_main item_detail\&item_id=12726\&item_no=1\&page_id=13\&block_id=21

McCafferty, S. G., Jacobs, G. M., \& Iddings, A. C. D. (2006). Cooperative learning and second language teaching. New York, NY: Cambridge University Press.

MEXT. (2014) 新たな未来を築くための大学教育の質的転換に向けて〜生涯学び続け、主体的に考える力 を育成する大学へ〜(答申)の概要 [Towards a qualitative conversion of university education for a new future: Abstract of the report on how colleges can cultivate skills on life-long learning and autonomous thinking]. Retrieved April 16, 2020, from http://www.mext.go.jp/component/b_ menu/shingi/toushin/__icsFiles/afieldfile/2012/09/10/1325048_4.pdf
MEXT. (2017). 新しい学習指導要領の考え方 一中央教育審議会における議論から改訂そして実施へ一 [Main ideas of the new educational guidelines for elementary and secondary education: The road from discussion, revision and implementation by the Central Council for Education]. Retrieved April 16, 2020, from https://www.mext.go.jp/a_menu/shotou/new-cs/__icsFiles/ afieldfile/2017/09/28/1396716_1.pdf

Mineshima, M. (2014). 協同学習を取り入れた大学での英語授業 : LTD話し合い学習法による効果の検証 [Cooperative learning in college English classes: A case study using the LTD method]. 中部地区英 語教育学会紀要 [Bulletin of Chubu English Language Education Society], 43, 281-286. https://doi.org/10.20713/celes.43.0_281

Nunan, D. (1992). Toward a collaborative approach to curriculum development: A case study. In D. Nunan (Ed.) Collaborative language learning and teaching (pp. 230-254). New York, NY: Cambridge University Press.

Sekita, K., \& Yasunaga, S. (2005). 協同学習の定義と関連用語の整理 [Definition of cooperative learning and related vocabulary]. 協同と教育[Kyoudou to Kyouiku], 1, 10-17.

Sharan, S. (1985). Cooperative learning and the multiethnic classroom. In R. E. Slavin, R. E. S. Sharan, S. Kagan, R. H. Lazarowitz, C. Well, \& R. Schmuck (Eds.), Learning to cooperate, cooperating to learn (pp. 255-262). Boston, MA: Springer.

Slavin, R. E. (1996). Research on cooperative learning and achievement: What we know, what we need to know. Contemporary Educational Psychology, 21, 43-69. https://doi.org/10.1006/ceps.1996.0004

Slavin, R. E. (2014). Making cooperative learning powerful. Instruction That Sticks, 72(2), 22-26. Retrieved from http://www.ascd.org/publications/educational-leadership/oct14/vol72/num02/ Making-Cooperative-Learning-Powerful.aspx

Stevens, R. J., Madden, N. A., Slavin, R. E., \& Farnish, A. M. (1987). Cooperative integrated reading and composition: Two field experiments. Reading Research Quarterly, 22(4), 433-454. Retrieved from http://www.jstor.org/stable/747701

Stevens, R. J., Slavin, R. E., \& Farnish, A. M. (1991). The effects of cooperative learning and direct instruction in reading comprehension strategies on main idea identification. Journal of Educational Psychology, 83(1), 8-16. http://dx.doi.org/10.1037/0022-0663.83.1.8

Storch, N. (2002). Patterns of interaction in ESL pair work. Language Learning, 52(1), 119-158. https://doi.org/10.1111/1467-9922.00179

Sugie, S. (2004). 協同学習による授業改善 [Cooperative learning and the improvement of school learning]. 教育心理学年報 [The Annual Report of Educational Psychology in Japan], 43, 156-165。 https://doi.org/10.5926/arepj1962.43.0_156 


\section{Appendix A}

Questionnaire on the Five Key Elements of CL (Original Japanese) 協同学習の5つの基本理念についての質問紙

$(1=$ 全く重要でない, $2=$ 重要でない, $3=$ どちらでもない, $4=$ 重要である, $5=$ 非常に重要である $)$

以下の項目は、協同学習においてどれくらい重要だと思いますか?

1. 課題を達成するためには、自分も相手も相互に力を出し合いつつ、助け合わなければいけな い。

2. ひざを突き合わせて座り、互いに励まし合いながら課題に取り組まなければならない。

3. メンバーは、自分が活動しなければグループ全体の学習が成り立たない事を自覚し、課題に取 り組む必要がある。

4. メンバーは円滑なコミュニケーションをはかるためのスキルを持っていなければならない。

5. グループは課題達成に向かっているかどうかを、定期的に振り返る必要がある。

Questionnaire on the Five Key Elements of CL (English Translation) How important do you think each of the following is when conducting cooperative learning?

$(1=$ not important at all, $2=$ not important, $3=$ neither unimportant nor important, $4=$ important, 5 = very important)

1. In order to complete the assignment, each group member must contribute to the group and help one another.

2. Group members must come to class, participate in group work, and encourage one another.

3. Group members must understand that group learning will not occur unless everyone actively participates in the assignment.

4. Group members must have good communication skills.

5. Group members must look back on how well their group work is going and confirm that they are on the same path to complete the assignment.

\section{Appendix B}

Understanding of the Five Key Elements of CL (Original Japanese)

協同学習の5つの基本理念の承諾書

1. 互恵的な相互依存

個人の成功はグループの成功と結びついている。グループの目標を達成するために、互いに助 け合い、尊重する。

2. 対面的で促進的な相互交涉

課題の遂行の為、対面し、互いに積極的に援助し合う。また、グループメンバーは互いの努力 を認め、励ましあう。

3. 個人としての責任

各々のグループメンバーが活動に貢献する責任があることを自覚し、個々人は自分が担当する 部分に関しては、確実に達成する。

4. 社会的スキルや小グループ運営スキル

各々がリーダーシップ、意思決定、信頼の確立、コミュニケーション、社会調整技術などを持つ。

5. グループの改善手続き

協同活動の評価を互いに個別にフィードバックする。

上記内容を理解し、協同学習を実施します。

\section{Understanding of the Five Key Elements of CL (English Translation)}

1. Positive interdependence

An individual's success is linked to the group's success as a whole. In order to achieve the group goal, individuals should help and respect one another.

2. Face-to-face promotive interaction

In order to complete the assignment, group members ought to actively help one another. Group members should also recognize each other's contributions and encourage one another.

3. Individual accountability

Each group member should recognize their responsibility to contribute to the group.

Members ought to make sure they complete their share of the work.

4. Interpersonal and small group skills

Each group member should possess the following skills: leadership, decision making, establishing trust, communication, and social adjustment. 


\section{Group processing \\ Group members should provide one another with individual feedback for the $\mathrm{CL}$ activity.}

I understand the principles above and will conduct $\mathrm{CL}$ activities according to these principles. 